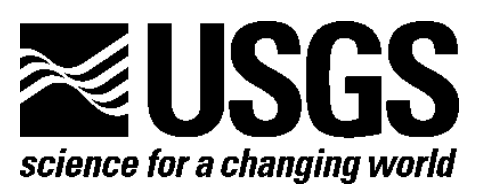

\title{
National Assessment of Shoreline Change-Summary Statistics for Updated Vector Shorelines and Associated Shoreline Change Data for the Gulf of Mexico and Southeast Atlantic Coasts
}

By Emily A. Himmelstoss, Meredith G. Kratzmann, and E. Robert Thieler

Open-File Report 2017-1015

U.S. Department of the Interior

U.S. Geological Survey 


\title{
U.S. Department of the Interior RYAN K. ZINKE, Secretary
}

\section{U.S. Geological Survey William H. Werkheiser, Acting Director}

\author{
U.S. Geological Survey, Reston, Virginia: 2017
} For more information on the USGS-the Federal source for science about the Earth,
its natural and living resources, natural hazards, and the environment-visit
https://www.usgs.gov/ or call 1-888-ASK-USGS (1-888-275-8747).

For an overview of USGS information products, including maps, imagery, and publications, visit https://store.usgs.gov/.

Any use of trade, firm, or product names is for descriptive purposes only and does not imply endorsement by the U.S. Government.

Although this information product, for the most part, is in the public domain, it also may contain copyrighted materials as noted in the text. Permission to reproduce copyrighted items must be secured from the copyright owner.

Suggested citation:

Himmelstoss, E.A., Kratzmann, M.G., and Thieler, E.R., 2017, National assessment of shoreline changeSummary statistics for updated vector shorelines and associated shoreline change data for the Gulf of Mexico and Southeast Atlantic coasts: U.S. Geological Survey Open-File Report 2017-1015, 8 p., https://doi.org/10.3133/ofr20171015.

ISSN 2331-1258 (online) 


\section{Acknowledgments}

This report was made possible by the hard work and generous cooperation of many individuals. We thank the National Oceanic and Atmospheric Administration for providing digital historical shorelines.

We extend special thanks to Caroline Roberts and Theresa Smith for their helpful efforts contributing to the compilation of additional shoreline data for the Gulf of Mexico and Southeast Atlantic coasts. 


\section{Contents}

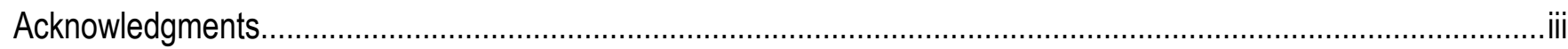

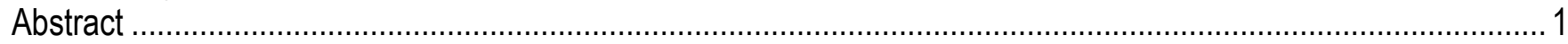

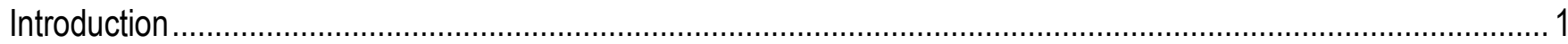

U.S. Geological Survey National Assessment of Shoreline Change Project.....................................................

Calculation and Interpretation of Shoreline Change Rates ……………...................................................... 3

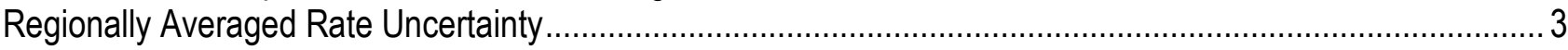

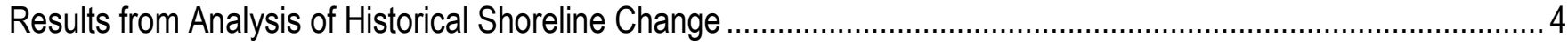

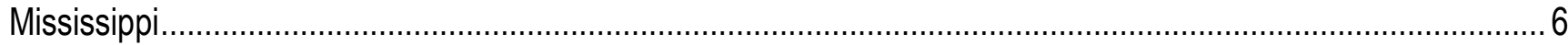

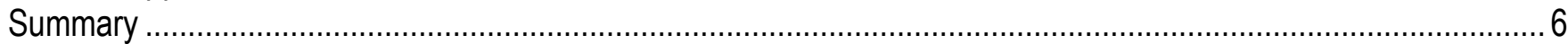

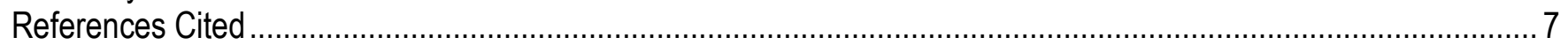

\section{Figures}

1. Map of the five States within the Gulf of Mexico region and the four States within the Southeast Atlantic region.

\section{Tables}

1. Average long-term shoreline change rates, percentage of transects eroding, and average rate uncertainties for the Gulf of Mexico and Southeast Atlantic regions . 4

2. Long-term maximum erosion and accretion rates and uncertainties for the Gulf of Mexico and Southeast Atlantic regions ...................................................................................................................... 5

3. Short-term maximum erosion and accretion distances and locations for the Gulf of Mexico and Southeast

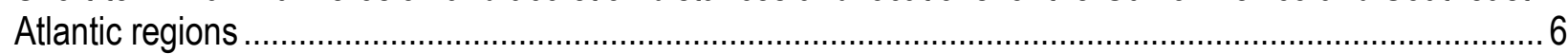




\section{Conversion Factors}

International System of Units to U.S. customary units

\begin{tabular}{|c|c|c|}
\hline Multiply & By & To obtain \\
\hline meter $(\mathrm{m})$ & 3.281 & foot (ft) \\
\hline kilometer (km) & 0.6214 & mile (mi) \\
\hline meter per year $(\mathrm{m} / \mathrm{yr})$ & 3.281 & foot per year (ft/yr) \\
\hline
\end{tabular}

Datum

Horizontal coordinate information is referenced to the World Geodetic System (WGS 84).

\section{Abbreviations}

$\mathrm{Cl}$

confidence interval

DSAS Digital Shoreline Analysis System

USGS U.S. Geological Survey 


\title{
National Assessment of Shoreline Change-Summary Statistics for Updated Vector Shorelines and Associated Shoreline Change Data for the Gulf of Mexico and Southeast Atlantic Coasts
}

\author{
By Emily A. Himmelstoss, Meredith G. Kratzmann, and E. Robert Thieler
}

\begin{abstract}
Long-term rates of shoreline change for the Gulf of Mexico and Southeast Atlantic regions of the United States have been updated as part of the U.S. Geological Survey's National Assessment of Shoreline Change project. Additional shoreline position data were used to compute rates where the previous rate-of-change assessment only included four shoreline positions at a given location. The longterm shoreline change rates also incorporate the proxy-datum bias correction to account for the unidirectional onshore bias of the proxy-based high water line shorelines relative to the datum-based mean high water shorelines. The calculation of uncertainty associated with the long-term average rates has also been updated to match refined methods used in other study regions of the National Assessment project. The average rates reported here have a reduced amount of uncertainty relative to those presented in the previous assessments for these two regions.
\end{abstract}

\section{Introduction}

\section{U.S. Geological Survey National Assessment of Shoreline Change Project}

Sandy ocean beaches are popular tourist and recreational destinations in the United States and constitute some of the most valuable real estate in the country. These dynamic interfaces between water and land are often locations of concentrated residential and commercial development and are frequently subjected to a range of natural hazards, which include flooding, storm effects, and coastal erosion. In response, the U.S. Geological Survey (USGS) is conducting a national assessment of coastal change hazards. One component of this research effort, the National Assessment of Shoreline Change project, documents changes in shoreline position as a proxy for coastal change. Shoreline position is one of the most commonly monitored indicators of environmental change (Morton, 1996), and it is an easily understood feature marking the location of a beach through time.

A principal component of the USGS National Assessment of Shoreline Change has been to develop a consistent methodology for calculating shoreline change rates and reporting results that may be periodically updated when additional data or improved techniques are available. Results have been organized and presented by coastal regions and include analyses and descriptive reports for the U.S. Gulf of Mexico coast (Morton and others, 2004), the Southeast Atlantic coast (Morton and Miller, 2005), the California sandy shorelines (Hapke and others, 2006) and California coastal cliffs (Hapke and 
Reid, 2007), the New England and Mid-Atlantic coasts (Hapke and others, 2011), parts of the Hawaii coast (Fletcher and others, 2012), the Pacific Northwest (Ruggiero and others, 2013), and parts of Alaska (Gibbs and Richmond, 2015).

This report is an update to the original Gulf of Mexico (Miller and others, 2004) and Southeast Atlantic (Miller and others, 2005) data and includes revised rate-of-change calculations based on additional shoreline position data, improved rate metrics, and application of a proxy-datum bias correction that quantifies potential bias and errors associated with integrating shorelines referenced to different proxies (Ruggiero and List, 2009). To be consistent with previous work, the Gulf of Mexico and Southeast Atlantic (fig. 1) study areas were organized by State for analysis.

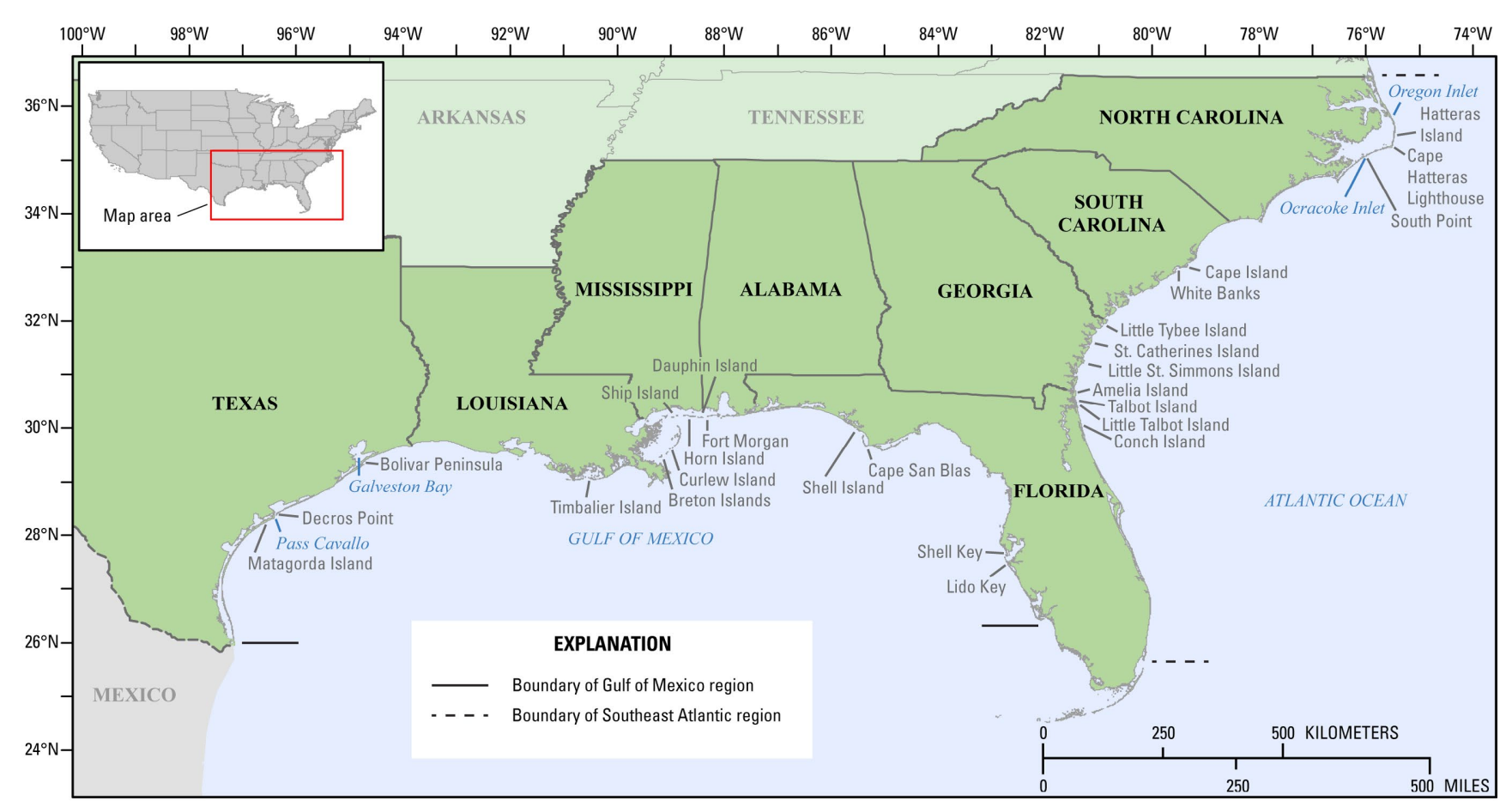

Figure 1. Map of the five States within the Gulf of Mexico region and the four States within the Southeast Atlantic region.

The USGS National Assessment of Shoreline Change analysis for the Gulf of Mexico and Southeast Atlantic coasts incorporates shoreline positions from a variety of data sources covering a range of dates. Data from the previously published National Assessment of Shoreline Change studies for these regions (Morton and others, 2004; and Morton and Miller, 2005) were the starting point for this update. In the initial reports, shoreline data were compiled for each State with the criterion of using only a single shoreline date within each of four specific time periods to compute rate metrics. Any additional shoreline data were omitted in an attempt to maintain consistency in the number of shorelines used for analysis among regions. The purpose of this update is to add all available shoreline data for each State into the National Assessment of Shoreline Change database and to compute updated shoreline rates of change that include the proxy-datum bias correction (Ruggiero and List, 2009; Ruggerio and others, 2003) that corrects for the bias between high water line and mean high water type shorelines. These data were incorporated from the National Oceanographic and Atmospheric Association, numerous universities, and State departments, which are listed in the metadata files for each shoreline dataset 
available in the data releases complementary to this report (Himmelstoss and others, 2017; Kratzmann and others, 2017).

The shoreline change results and products prepared by the USGS are not intended for detailed site-specific analysis of shoreline movement, nor are they intended to replace any official sources of shoreline change information identified by local or State government agencies or other federal entities for regulatory uses. Rates of shoreline change presented in this report represent shoreline movement under past conditions. The results are not intended for predicting future shoreline positions or future rates of shoreline change. Rates of shoreline change published in this report are for the purpose of a regional characterization of shoreline behavior through time. Individual measurement transects for the entire Gulf of Mexico (Himmelstoss and others, 2017) and Southeast Atlantic (Kratzmann and others, 2017) regions, as well as the other open-ocean shoreline regions along the United States coast, can be viewed in the U.S. Geological Survey Coastal Change Hazards Portal (https://marine.usgs.gov/coastalchangehazardsportal/).

\section{Calculation and Interpretation of Shoreline Change Rates}

Rates of long-term (>80 years) and short-term (20-50 years) shoreline change for the Gulf of Mexico and Southeast Atlantic coasts were produced by using the linear regression and end point rate calculation methods included in the Digital Shoreline Analysis System (DSAS), versions 4.2 and 4.3 (Thieler and others, 2012). For this study, DSAS was used to generate orthogonal transects at 50-meter spacing along the coast and to subsequently calculate change statistics. The shoreline change rates and rate uncertainties at individual transect locations are available in data releases for the Gulf of Mexico and Southeast Atlantic regions respectively (Himmelstoss and others, 2016; Kratzmann and others, 2016). This report provides State-averaged rates of long-term shoreline change and the associated average rate uncertainty as a measure of broader scale trends. Maximum values of erosion and accretion are reported for both long- and short-term rates at individual locations for each State.

\section{Regionally Averaged Rate Uncertainty}

Following the approach of Ruggiero and others (2013), we estimated that each transect rate uncertainty was partially independent of the others. To estimate the regionally averaged uncertainty of partially independent transect rates, we first evaluated the effective number of independent uncertainty values, $n^{*}$. Following Garrett and Toulany (1981), we found $n^{*}$ on the basis of the spatially lagged autocorrelation of each measure of shoreline change rate uncertainty. In all States, this method resulted in a large reduction in the original sample size, $n$, shown in table 1. Assuming that the uncertainty of a region can be represented by $\bar{U}_{R}$, we found the uncertainty of a regionally averaged change rate $\left(\bar{U}_{R_{q^{*}}}\right)$ as follows:

$$
\bar{U}_{R_{q^{*}}}=\frac{1}{\sqrt{n^{*}}} \bar{U}_{R}
$$

The reduced effective sample size $\left(n^{*}\right)$ was also determined for each region (Gulf of Mexico as one sample and all of the Southeast Atlantic as another) by summing the $n^{*}$ values for individual States within the region. Average uncertainty values found using equation 1, as reported in table 1, are generally much smaller than the arithmetic mean confidence interval (CI) but larger than the quadratureaveraged CI. 
Table 1. Average long-term shoreline change rates, percentage of transects eroding, and average rate uncertainties for the Gulf of Mexico and Southeast Atlantic regions.

[Uncertainty numbers in bold are confidence interval values that are less than the average rate, indicating that the rates are statistically significant. $\mathrm{m} / \mathrm{yr}$, meter per year; m, meter; $n$, sample size]

\begin{tabular}{|c|c|c|c|c|c|c|c|}
\hline State & $\begin{array}{l}\text { Number of } \\
\text { measurement } \\
\text { transects }\end{array}$ & $\begin{array}{l}\text { Percent of total } \\
\text { transects } \\
\text { measuring } \\
\text { erosion }\end{array}$ & \multicolumn{2}{|c|}{$\begin{array}{l}\text { Average rate }(\mathrm{m} / \mathrm{yr}) \text { with } \\
\text { average uncertainty (m/yr) } \\
\text { for all transects }\end{array}$} & $\begin{array}{c}\text { Independent } \\
n\end{array}$ & \multicolumn{2}{|c|}{$\begin{array}{l}\text { Average rate }(\mathrm{m} / \mathrm{yr}) \text { with } \\
\text { uncertainty }(\mathrm{m} / \mathrm{yr}) \text { reduced } \\
\text { for independent } n\end{array}$} \\
\hline \multicolumn{8}{|c|}{ Gulf of Mexico region } \\
\hline Texas & 11,942 & 65 & -0.6 & \pm 0.9 & 31 & -0.6 & \pm 0.2 \\
\hline Louisiana & 3,789 & 89 & -7.7 & \pm 6.2 & 46 & -7.7 & \pm 0.9 \\
\hline Mississippi & 970 & 35 & 0.2 & \pm 1.6 & 58 & 0.2 & \pm 0.2 \\
\hline Alabama & 1,457 & 74 & -0.5 & \pm 0.9 & 22 & -0.5 & \pm 0.2 \\
\hline Florida & 11,901 & 58 & -0.1 & \pm 1.03 & 161 & -0.1 & $\pm \mathbf{0 . 0 8}$ \\
\hline Total & 30,059 & 65 & -1.7 & \pm 2.1 & 319 & -1.7 & \pm 0.02 \\
\hline \multicolumn{8}{|c|}{ Southeast Atlantic region } \\
\hline $\begin{array}{l}\text { North } \\
\text { Carolina }\end{array}$ & 10,192 & 71 & -0.5 & \pm 0.9 & 275 & -0.5 & \pm 0.06 \\
\hline $\begin{array}{l}\text { South } \\
\text { Carolina }\end{array}$ & 5,833 & 54 & -0.6 & \pm 2.7 & 43 & -0.6 & \pm 0.4 \\
\hline Georgia & 2,944 & 41 & 0.7 & \pm 2.5 & 65 & 0.7 & \pm 0.3 \\
\hline Florida & 11,790 & 43 & 0.1 & \pm 0.6 & 203 & 0.1 & \pm 0.04 \\
\hline Total & 30,759 & 54 & -0.07 & \pm 1.7 & 586 & -0.07 & \pm 0.01 \\
\hline
\end{tabular}

\section{Results from Analysis of Historical Shoreline Change}

Regionally averaged rates of long-term shoreline change and the associated average values of rate uncertainty for the Gulf of Mexico and Southeast Atlantic coasts are presented in table 1. These are updates of values from the previously published reports for the study regions, in which the geomorphology and coastal characteristics are described in detail (Morton and others, 2004; Morton and Miller, 2005). Nearly all State-averaged long-term rates are statistically significant in this update, resulting in a more scientifically robust dataset.

The State with the greatest average erosional rate of shoreline change in the Gulf of Mexico region is Louisiana $(-7.7 \pm 0.9$ meters per year $[\mathrm{m} / \mathrm{yr}])$, where erosion occurred at 89 percent of the measurement transect locations (table 1). The greatest maximum long-term erosion rate at an individual measurement transect within the entire Gulf of Mexico region is for a transect in Louisiana $(-32.3 \pm$ $32.4 \mathrm{~m} / \mathrm{yr}$; table 2). The greatest maximum long-term accretion rate at an individual measurement transect within the Gulf of Mexico region is for a transect in Texas $(33.5 \pm 13.5 \mathrm{~m} / \mathrm{yr}$; table 2).

The State with the greatest average erosional rate of shoreline change in the Southeast Atlantic region is South Carolina $(-0.6 \pm 0.4 \mathrm{~m} / \mathrm{yr})$, where erosion occurred at 54 percent of the measurement transect locations. North Carolina, however, has the greatest percentage of transects with erosional rates (71 percent; table 1). The greatest maximum long-term erosion rate at an individual measurement 
transect within the entire Southeast Atlantic region is for a transect in South Carolina $(-17.4 \pm$ $7.01 \mathrm{~m} / \mathrm{yr}$; table 2). The greatest maximum long-term accretion rate at an individual measurement transect within the Southeast Atlantic region is for a transect in South Carolina $(27.4 \pm 14.1 \mathrm{~m} / \mathrm{yr}$; table 2). The updated long-term average rates for each State are statistically significant, meaning the average rate plus or minus the uncertainty associated with the rate reports a range of values that are entirely negative, indicating erosion, or entirely positive, signifying accretion through time.

Table 2. Long-term maximum erosion and accretion rates and uncertainties for the Gulf of Mexico and Southeast Atlantic regions.

[Maximums in bold are the greatest erosion and accretion rates for each region. $\mathrm{m} / \mathrm{yr}$, meter per year; $\mathrm{m}$, meter]

\begin{tabular}{|c|c|c|c|c|c|c|}
\hline State & $\begin{array}{c}\text { Maximum } \\
\text { erosion } \\
(\mathrm{m} / \mathrm{yr})\end{array}$ & $\pm(\mathrm{m})$ & Location & $\begin{array}{c}\text { Maximum } \\
\text { accretion } \\
(\mathrm{m} / \mathrm{yr})\end{array}$ & $\pm(\mathrm{m})$ & Location \\
\hline \multicolumn{7}{|c|}{ Gulf of Mexico region } \\
\hline Texas & -15.4 & 1.1 & $\begin{array}{l}\text { Matagorda Island, near Pass } \\
\text { Cavallo }\end{array}$ & 33.5 & 13.5 & Decros Point \\
\hline Louisiana & -32.3 & 32.4 & Palos Island & 19.6 & 19.4 & Timbalier Island \\
\hline Mississippi & -13.0 & 6.4 & Horn Island & 9.1 & 9.9 & Horn Island \\
\hline Alabama & -3.9 & 4.4 & Fort Morgan & 8.5 & 2.2 & West end of Dauphin Island \\
\hline Florida & -10.6 & 26.4 & Crooked Island & 12.4 & 19.4 & Honeymoon Island \\
\hline \multicolumn{7}{|c|}{ Southeast Atlantic region } \\
\hline $\begin{array}{l}\text { North } \\
\text { Carolina }\end{array}$ & -9.5 & 1.1 & Bodie Island, Oregon Inlet & 11.5 & 6.1 & $\begin{array}{l}\text { Hatteras Island, south of } \\
\text { lighthouse }\end{array}$ \\
\hline $\begin{array}{l}\text { South } \\
\text { Carolina }\end{array}$ & -17.4 & 7.01 & Lighthouse Island & 27.4 & 14.1 & North end of Cape Island \\
\hline Georgia & -8.01 & 1.2 & St. Catherines Island & 23.3 & 9.0 & Little Saint Simmons Island \\
\hline Florida & -5.84 & 2.1 & Long Island & 11.9 & 4.8 & North end of Conch Island \\
\hline
\end{tabular}

Short-term (20-50 years) changes, measured as the distance between the oldest and most recent shoreline features within the time period, are presented in table 3 . The number of shorelines available at individual transect measurement locations in the short-term timespan varied significantly, and the linear regression rates could not be calculated completely across each State. Therefore, the short-term results are reported as distances between the oldest and most recent shoreline positions. The greatest maximum short-term erosional distance at an individual measurement transect within the Gulf of Mexico region is for a transect in Louisiana. The shoreline moved 2,847 meters landward between 1978 and 1996 (table 3). The greatest maximum short-term accretional distance for the Gulf of Mexico region is for a transect in Texas. The shoreline moved 1,584 meters seaward between 1962 and 2001. The greatest maximum short-term erosional distance at an individual measurement transect within the Southeast Atlantic region is for a transect in South Carolina. The shoreline moved 904 meters landward between 1962 and 2000 (table 3). The greatest maximum short-term accretional distance for the Southeast Atlantic region is also for a transect in South Carolina. The shoreline moved 1,814 meters seaward between 1962 and 2000. 
Table 3. Short-term maximum erosion and accretion distances and locations for the Gulf of Mexico and Southeast Atlantic regions.

[Maximums in bold are the greatest erosion and accretion distances for each region. $\mathrm{m}$, meter]

\begin{tabular}{|c|c|c|c|c|c|c|c|c|}
\hline State & $\begin{array}{l}\text { Maximum } \\
\text { erosion } \\
\text { (m) }\end{array}$ & $\begin{array}{l}\text { Time } \\
\text { period }\end{array}$ & Years & Location & $\begin{array}{l}\text { Maximum } \\
\text { accretion } \\
\text { (m) }\end{array}$ & $\begin{array}{l}\text { Time } \\
\text { period }\end{array}$ & Years & Location \\
\hline \multicolumn{9}{|c|}{ Gulf of Mexico region } \\
\hline Texas & -701 & $\begin{array}{l}1965- \\
2001\end{array}$ & 36 & $\begin{array}{l}\text { Matagorda Island, } \\
\text { near Pass Cavallo }\end{array}$ & 1,584 & $\begin{array}{l}1962- \\
2001\end{array}$ & 39 & $\begin{array}{l}\text { Bolivar Peninsula, } \\
\text { near Galveston Bay }\end{array}$ \\
\hline Louisiana & $-2,847$ & $\begin{array}{l}1978- \\
1996\end{array}$ & 18 & Timbalier Island & 1,578 & $\begin{array}{l}1978- \\
2001\end{array}$ & 23 & Breton Islands \\
\hline Mississippi & -576 & $\begin{array}{l}1966- \\
2001\end{array}$ & 35 & $\begin{array}{l}\text { Ship Island, west side } \\
\text { of Camille Cut }\end{array}$ & 315 & $\begin{array}{l}1966- \\
2001\end{array}$ & 35 & $\begin{array}{l}\text { West end of Horn } \\
\text { Island }\end{array}$ \\
\hline Alabama & -238 & $\begin{array}{l}1981- \\
2001\end{array}$ & 20 & Fort Morgan & 140 & $\begin{array}{l}1981- \\
2001\end{array}$ & 20 & $\begin{array}{l}\text { West end of Dauphin } \\
\text { Island }\end{array}$ \\
\hline Florida & -335 & $\begin{array}{r}1977- \\
1998\end{array}$ & 21 & $\begin{array}{l}\text { East side of Cape San } \\
\text { Blas }\end{array}$ & 817 & $\begin{array}{r}1971- \\
1998\end{array}$ & 27 & South end of Lido Key \\
\hline \multicolumn{9}{|c|}{ Southeast Atlantic region } \\
\hline $\begin{array}{l}\text { North } \\
\text { Carolina }\end{array}$ & -655 & $\begin{array}{l}1974- \\
1997\end{array}$ & 23 & $\begin{array}{l}\text { South Point, } \\
\text { Ocracoke Inlet }\end{array}$ & 811 & $\begin{array}{r}1963- \\
2009\end{array}$ & 46 & $\begin{array}{l}\text { South side of Cape } \\
\text { Hatteras Lighthouse }\end{array}$ \\
\hline $\begin{array}{l}\text { South } \\
\text { Carolina }\end{array}$ & -904 & $\begin{array}{l}1962- \\
2000\end{array}$ & 38 & Center of Cape Island & 1,814 & $\begin{array}{l}1962- \\
2000\end{array}$ & 38 & $\begin{array}{l}\text { North end of Cape } \\
\text { Island }\end{array}$ \\
\hline Georgia & -381 & $\begin{array}{l}1971- \\
1999\end{array}$ & 28 & Little Tybee Island & 613 & $\begin{array}{r}1971- \\
1999\end{array}$ & 28 & $\begin{array}{l}\text { Southernmost end of } \\
\text { Little Tybee Island }\end{array}$ \\
\hline Florida & -383 & $\begin{array}{r}1973- \\
1999\end{array}$ & 26 & $\begin{array}{l}\text { South end of Amelia } \\
\text { Island }\end{array}$ & 901 & $\begin{array}{r}1963- \\
1999\end{array}$ & 36 & $\begin{array}{l}\text { North end of Little } \\
\text { Talbot Island }\end{array}$ \\
\hline
\end{tabular}

\section{Mississippi}

In addition to adding more shoreline position data at locations already covered in the previous report (Morton and others, 2004), data covering more than 16 kilometers of coast not mapped previously were added to the data for Mississippi. Some of this new shoreline position data measured accretion. This resulted in an updated accretional (positive) long-term State average for Mississippi, whereas the original study reported an erosional (negative) State average. This is the only State for which the average rate in this updated report has a different sign than the original long-term State average from the previous study.

\section{Summary}

The U.S. Geological Survey updated calculations of long-term rates of shoreline change for the Gulf of Mexico and Southeast Atlantic regions as part of the National Assessment of Shoreline Change project. The updated calculations incorporate additional shoreline position data for locations where the original rates were calculated from only four shorelines. In most States, the updated shoreline data extend coverage along the State coastline, meaning these updated averages provide a more comprehensive measure of shoreline change along the coast. The change measurements for the long- 
term rates also incorporate the proxy-datum bias correction to account for the high water line shorelines being biased onshore relative to the mean high water shorelines. The calculation of uncertainty associated with the long-term average rates has also been refined. As a result, the new average rates have less uncertainty than those presented in the original reports. Individual measurement transects for the entire Gulf of Mexico and Southeast Atlantic regions, as well as the other open-ocean shoreline regions along the United States coast, can be viewed in the U.S. Geological Survey Coastal Change Hazards Portal (https://marine.usgs.gov/coastalchangehazardsportal/).

\section{References Cited}

Fletcher, C.H., Romine, B.M., Genz, A.S., Barbee, M.M., Dyer, Matthew, Anderson, T.R., Lim, S.C., Vitousek, Sean, Bochicchio, Christopher, and Richmond, B.M., 2012, National assessment of shoreline change-Historical shoreline changes in the Hawaiian Islands: U.S. Geological Survey Open-File Report 2011-1051, 55 p.

Garrett, C.J.R., and Toulany, Bechara, 1981, Variability of the flow through the Strait of Belle Isle: Journal of Marine Research, v. 39, no. 1, p. 163-189.

Gibbs, A.E., and Richmond, B.M., 2015, National assessment of shoreline change-Historical shoreline changes along the North Coast of Alaska, U.S.-Canadian border to Icy Cape: U.S. Geological Survey Open-File Report 2015-1048, 96 p., https://dx.doi.org/10.3133/ofr20151048.

Hapke, C.J., Himmelstoss, E.A., Kratzmann, M.G., List, J.H., and Thieler, E.R., 2011, National assessment of shoreline change-Historical shoreline change along the New England and midAtlantic coasts: U.S. Geological Survey Open-File Report 2010-1118, 57 p., https://pubs.usgs.gov/of/2010/1118/.

Hapke, C.J., and Reid, David, 2007, National assessment of shoreline change, Part 4-Historical coastal cliff retreat along the California coast: U.S. Geological Survey Open-File Report 2007-1133, 51 p., https://pubs.usgs.gov/of/2007/1133/.

Hapke, C.J., Reid, David, Richmond, B.M., Ruggiero, Peter, and List, Jeff, 2006, National assessment of shoreline change Part 3-Historical shoreline change and associated coastal land loss along the sandy shorelines of the California coast: U.S. Geological Survey Open-File Report 2006-1219, 72 p., https://pubs.usgs.gov/of/2006/1219/.

Himmelstoss, E.A., Kratzmann, M.G., and Thieler, E.R., 2017, National assessment of shoreline change-A GIS compilation of updated vector shorelines and associated shoreline change data for the Gulf of Mexico coast: U.S. Geological Survey data release, accessed May 2017 at https://doi.org/10.5066/F78P5XNK.

Kratzmann, M.G., Himmelstoss, E.A., and Thieler, E.R., 2017, National assessment of shoreline change-A GIS compilation of updated vector shorelines and associated shoreline change data for the Southeast Atlantic coast: U.S. Geological Survey data release, accessed May 2017 at https://doi.org/10.5066/F74X55X7.

Miller, T.L., Morton, R.A., and Sallenger, A.H., 2005, The national assessment of shoreline change-A GIS compilation of vector shorelines and associated shoreline change data for the U.S. Southeast Atlantic coast: U.S. Geological Survey Open-File Report 2005-1326, accessed April 7, 2010, at https:/pubs.usgs.gov/of/2005/1326/.

Miller, T.L., Morton, R.A., Sallenger, A.H., and Moore, L.J., 2004, The national assessment of shoreline change-A GIS compilation of vector shorelines and associated shoreline change data for the U.S. Gulf of Mexico: U.S. Geological Survey Open-File Report 2004-1089, accessed May 14, 2009, at https://pubs.usgs.gov/of/2004/1089/. 
Morton, R.A., 1996, Geoindicators of coastal wetlands and shorelines, in Berger, A.R., and Iams, W.J., eds., Geoindicators-Assessing rapid environmental change in Earth systems: Rotterdam, Netherlands, A.A. Balkema, p. 207-230.

Morton, R.A., and Miller, T.L., 2005, National assessment of shoreline change-Part 2-Historical shoreline changes and associated coastal land loss along the U.S. Southeast Atlantic coast: U.S. Geological Survey Open-File Report 2005-1401, 35 p., accessed April 7, 2010, at https://pubs.usgs.gov/of/2005/1401/.

Morton, R.A., Miller, T.L., and Moore, L.J., 2004, National assessment of shoreline change-Part 1Historical shoreline changes and associated coastal land loss along the U.S. Gulf of Mexico: U.S. Geological Survey Open-File Report 2004-1043, 42 p., accessed May 14, 2009, at https://pubs.usgs.gov/of/2004/1043/.

Ruggiero, Peter, Kaminsky, G.M., and Gelfenbaum, Guy, 2003, Linking proxy-based and datum-based shorelines on high-energy coastlines-Implications for shoreline change analyses: Journal of Coastal Research, Special Issue 38, p. 57-82.

Ruggiero, Peter, Kratzmann, M.G., Himmelstoss, E.A., Reid, David, Allan, John, and Kaminsky, George, 2013, National assessment of shoreline change-Historical shoreline change along the Pacific Northwest coast: U.S. Geological Survey Open-File Report 2012-1007, 61 p. [Also available at https://dx.doi.org/10.3133/ofr20121007.]

Ruggiero, Peter, and List, J.H., 2009, Improving accuracy and statistical reliability of shoreline position and change rate estimates: Journal of Coastal Research, v. 25, no. 5, p. 1069-1081.

Thieler, E.R., Himmelstoss, E.A., Zichichi, J.L., and Ergul, Ayhan, 2012, The Digital Shoreline Analysis System (DSAS) version 4.0-An ArcGIS extension for calculating shoreline change (ver. 4.3.4730, April 2012): U.S. Geological Survey Open-File Report 2008-1278, accessed June 1, 2012, at https://pubs.er.usgs.gov/publication/ofr20081278/. 